\title{
nucture
}

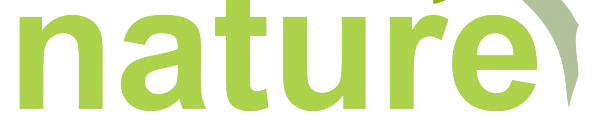

National Academic Journal of Architecture

\section{GEDUNG KONVENSI DI MAMMINASATA KABUPATEN GOWA SULAWESI SELATAN}

\author{
Taufik Arfan', Irma Rahayu ${ }^{2}$, Abd Rahman ${ }^{3}$ \\ Jurusan Arsitektur Fakultas Sains \& Teknologi UIN-Alauddin Makassar
}

\begin{abstract}
Abstrak-Kabupaten Gowa memiliki prospek pembangunan dan komersial yang sangat potensial untuk pembangunan pusat pertemuan di Sulawesi Selatan. Untuk mewadahi kegiatan tersebut perlu adanya gedung konvensi yang berkonsep berkelanjutan (sustainable) yang memadai dan dikelolah secara profesional. Tujuan laporan perancangan ini adalah menyusun suatu konsep perancangan melalui studi literatur, survey dan studi preseden dalam merencanakan dan merancang Gedung Konvensi di Mamminasata Kabupaten Gowa-Sulawesi Selatan. Metode yang dilakukan ialah dengan metode deskriptif, yaitu menguraikan, menjabarkan, dan menjelaskan tentang faktor-faktor yang dibutuhkan dalam perencanaan dan faktor yang menentukan desain. Hasil dari perancangan ini mentransformasikan konsep perancangan ke dalam desain Gedung Konvensi di Mamminasatan Kabupaten Gowa-Sulawesi Selatan. Selain itu meninjau spesifik dari Gedung Konvensi di Mamminasata Kabupaten Gowa yang merupakan syarat- syarat perencanaan yang meliputi: lokasi dan site, material dan struktur, Sirkulasi dan lingkungan, serta penampilan bangunan dan penataan ruang luar
\end{abstract}

Kata kunci: Gedung Konvensi. Maminasata

Abstract- Gowa has bright prospects and commercial potency in developing and contructing the convention center in South Sulawesi. To facilitate those activities it needs the convention center which has adequate sustainable and profesional managemnet. The purpose of this research is to develop a design concept through literature studies, surveys and precedent studies in planning and designing a Convention Center in Mamminasata-Gowa of South Sulawesi. The method used is descriptive method, which outlines, describes, and explains the factors in determining the design. The results of this design is to transform the design concepts into the Convenrion Center's design in Mamminasatan-Gowa of South Sulawesi. Besides that it also reviews the specific Convention Canter in Mamminasata Gowa which is the required in planning includes: the location and site, material and structure, circulation and the environment, building's appearance and arrangement of outer space

1Dosen Jurusan Teknik Arsitektur UIN Alauddin Makassar 2Dosen Jurusan Teknik Arsitektur UIN Alauddin Makassar 


\section{nucture \\ nature}

National Academic Journal of Architecture

\section{PENDAHULUAN}

Bisnis pariwisata memberikan kecerahan bagi pergerakan roda ekonomi nasional. Multiplier effect dari bisnis ini secara signifikan memberikan gairah investasi yang cukup menjanjikan. Investasi pada bisnis penyedia jasa diantaranya, traveling, bisnis perhotelan, souvenir, panti pijat, transportasi darat, laut dan udara, sampai dunia perbankan pun turut terimbasi bisnis pariwisata ini. Dampak lain dari maraknya industri pariwisata ini adalah terserapnya tenaga kerja lokal, baik skilled labor maupun unskilled labor. Bisnis pariwisata cukup memberikan angin segar bagi ekonomi nasional, terlebih pengeluaran pemerintah sangat tergantung pada penyediaan devisa melalui pajak dalam negeri. Dapat diprediksi dampak yang ditimbulkan bilamana sektor riil, termasuk bisnis pariwisata ini lumpuh, bahwa sebagian besar roda ekonomi nasional pun terkena dampaknya. (http://komitmenku.wordpress.com, diakses14 Mei 2015).

Berbagai program pemerintah untuk meningkatkan kinerja kepariwisataan Indonesia sebagai sektor andalan pembangunan nasional terus dilakukan, antara lain dengan menyelenggarakan program Visit Indonesia Year yang terakhir ini dilaksanakan pada tahun 2009 dengan tema "Marine \& MICE". Penyelenggaraan MICE diharapkan dapat meningkatkan jumlah kunjungan wisatawan nusantara, domestik dan mancanegara ke Indonesia untuk mengejar target jumlah kunjungan yang telah ditetapkan. Dalam rangka mendukung program tersebut, Kementerian Kebudayaan dan Pariwisata telah menetapkan 13 destinasi MICE (meeting, incentive, convention, and exhibition) unggulan, yaitu Jakarta, Yogyakarta, Surabaya, Bali, Balikpapan, Medan, Batam-Bintan, Padang-Bukittinggi, Makassar, Manado, Palembang, Mataram, dan Bandung. (http://www.budpar.go.id, diakses 14 Mei 2015).

Perkembangan kegiatan konvensi merupakan bagian dari industri pariwisata MICE (Meeting, Incentive, Conference, Exhibition) masa kini telah memberikan "warna dalam kegiatan bisnis industri pariwisata dunia", kegiatan konvensi memberikan beragam konstribusi terhadap kegiatan pariwisata, yang sangat menonjol adalah identik dengan pemberian pelayan/services. MICE dan bisnis pariwisata merupakan bisnis dengan high- quality dan high-income, yang memberikan kontribusi tinggi secara ekonomi terlebih bagi negara berkembang karena dalam pelaksanaannya banyak sekali menggunakan fasilitas pariwisata.

Kabupaten Gowa merupakan salah satu kabupaten yang masuk dalam kawasan Kota Metropolitan Mamminasata, yang mencakup 11 (sebelas) wilayah kecamatan, I meliputi Kecamatan Somba Opu, Kecamatan Bontomarannu, Kecamatan Pallangga, Kecamatan Bajeng, Kecamatan Bajeng Barat, Kecamatan Barombong, Kecamatan Manuju, Kecamatan Pattallassang, Kecamatan Parangloe, Kecamatan Bontonompo, dan Kecamatan Bontonompo Selatan. Karena masuk dalam kawasan tersebut sudah tentu dilengkapi dengan sarana dan prasarana yang memadai yaitu jalan bypass 


\section{nucture}

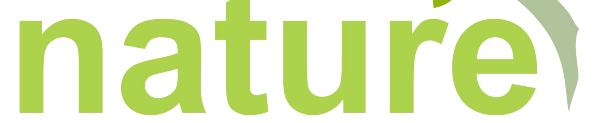

National Academic Journal of Architecture

mamminasata, jalur kereta api dan jalan angkutan umum. (Aglomerasi Mamminasata, 2013 : V-3)

Dilihat dari potensi pengembangannya ke depan, Kabupaten Gowa memiliki prospek pembangunan dan komersial yang sangat potensial untuk pembangunan pusat pertemuan di Sulawesi Selatan. Untuk mewadahi kegiatan tersebut perlu adanya gedung konvensi yang berkonsep berkelanjutan (sustainable) yang memadai dan dikelolah secara profesional. Pembahasan dibatasi pada masalahmasalah perencanaan desain fisik bangunan yang berkaitan dengan arsitektur berkelanjutan yaitu, bentuk, pencahayaan, penghawaan dan penataan ruang luar Gedung Konvensi di Mamminasata Kabupaten Gowa Sulawesi-Selatan.

\section{METODE PERANCANGAN}

Metode pembahasan dilakukan dengan metode deskriptif, yaitu menguraikan, menjabarkan, dan menjelaskan tentang faktor-faktor yang dibutuhkan dalam perencanaan dan faktor yang menentukan desain. Berdasarkan hal tersebut, akan diadakan pengumpulan data yang diperlukan kemudian dijabarkan dalam bentuk tabel, gambar, desain gambar dan maket serta dianalisa untuk menghasilkan kesimpulan, batasan dan anggapan yang akan digunakan sebagai dasar dari perencanaan dan perancangan Gedung Konvensi di Mamminasatan Kabupaten Gowa-Sulawesi Selatan.

Data yang diperoleh berasal dari data sekunder, yaitu studi literatur melalui buku, makalah, referensi, standar, internet dan sumber-sumber tertulis yang berhubungan dengan perencanaan dan perancangan Gedung Konvensi di Mamminasatan Kabupaten Gowa-Sulawesi Selatan.dikaitkan pada penerapan arsitektur lokal.

\section{A. Konsep Tapak}

\section{KONSEP DESAIN}

Konsep utama desain tapak yaitu kenyamanan aktivitas sirkulasi manusia dan kendaraan, dan kesesuaian zoning elemen-elemen tapak, perencana ingin agar aktivitas sirkulasi dalam tapak berjalan lancar, dan penempatan elemen tapak sesuai dengan sifat zoningnya, misalnya penempatan pintu masuk tapak yang sifatnya publik maka perlu diletakkan di area depan yang berhubungan langsung dengan jalan utama sedangkan bangunan utama yang sifatnya privat maka diletakkan di area yang lebih khusus.

Desain tapak juga menyesuaikan dengan bentuk lahan yang memanjang ke belakang, maka hal ini berpengaruh terhadap bentuk bangunan, model lahan parkir, letak ruang terbuka hijau dan posisi elemen lainnya. 


\section{nucture naturel}

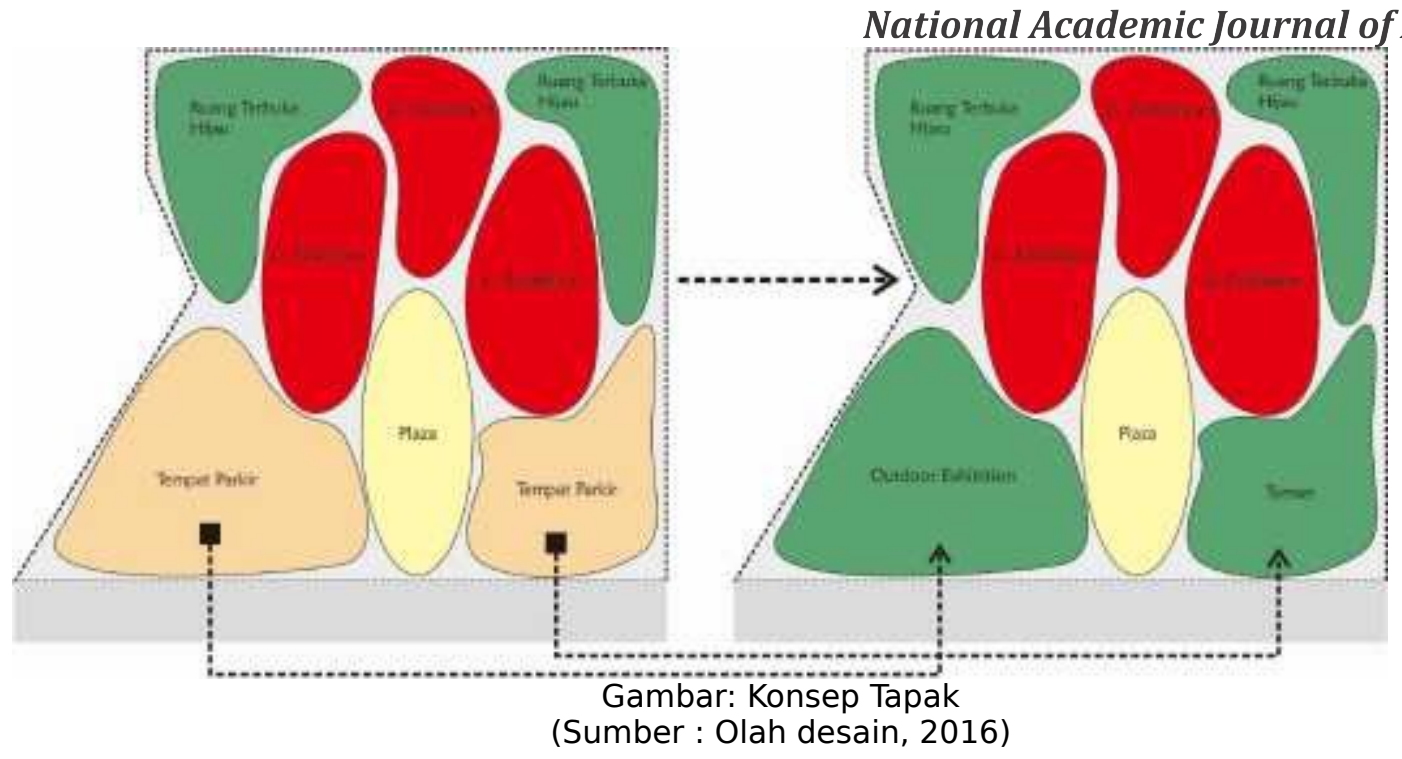

Gagasan awal perencanaan tapak seperti pada gambar (A), sedangkan gagasan akhir yang terealisasi seperti pada gambar (B), kemudian tempat parkir kendaraan dipindahkan ke basement.

\section{B. Desain Bentuk}

Ide konsep bentuk terinspirasi dari bentuk petunjuk arah, yang dikembangkan lebih jauh dengan kombinasi material-material modern dan ramah lingkungan, hal ini bertujuan agar tercapai konsep desain gedung konvensi, dimana desain menunjukkan ciri arsitektur berkelanjutan. 


\section{nucture}

naturel

National Academic Journal of Architecture

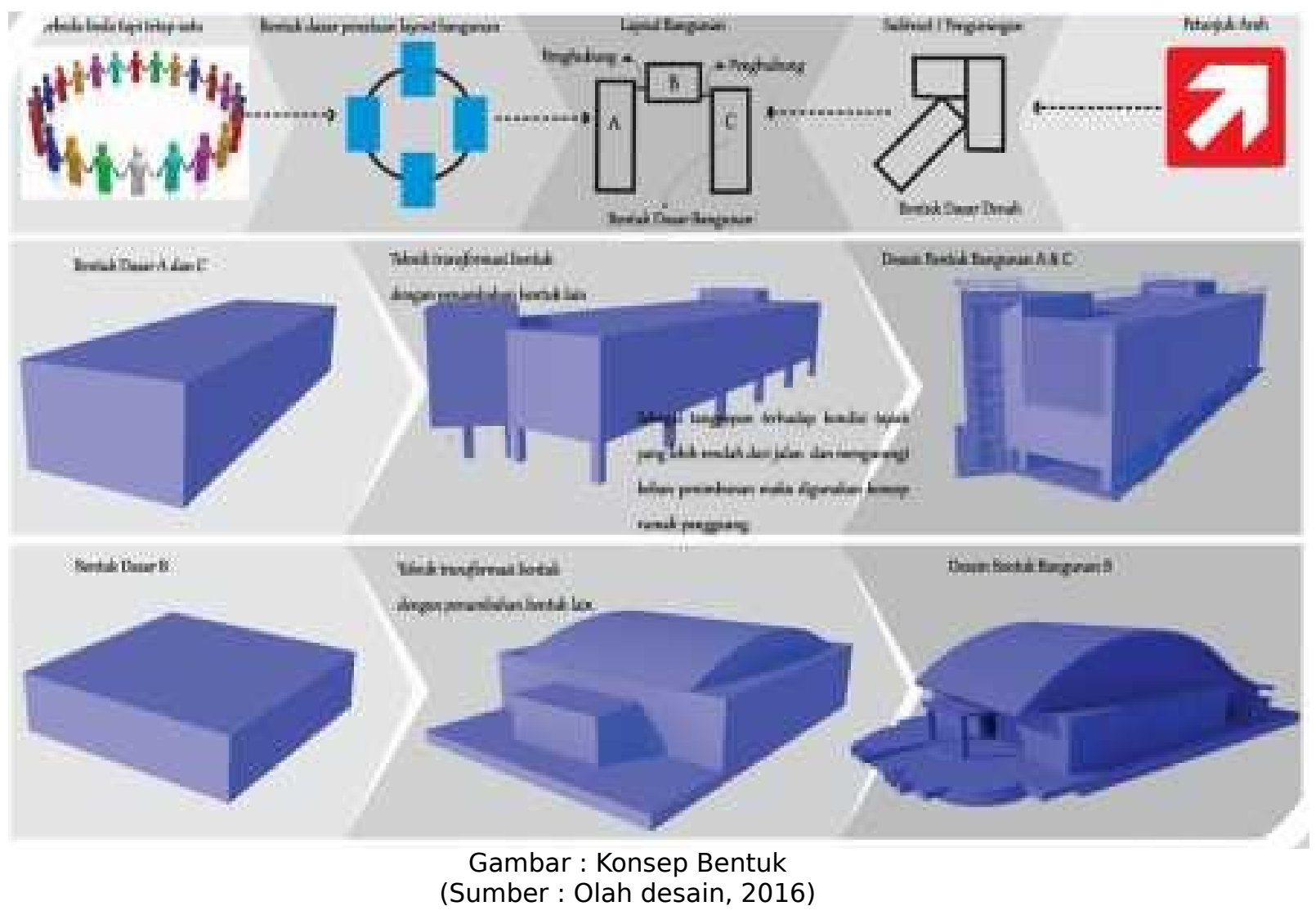

\section{Konsep Material dan Struktur}

Sistem substruktur menggunakan pondasi tiang pancang dengan material besi dan beton. Sistem superstruktur menggunakan sistem rigid frame dengan material kolom dan balok menggunakan baja honeycomb dan selimut beton. Sistem upperstruktur menggunakan atap plat untuk gedung pameran dengan material beton dan bondeks serta material kedap air, sedangkan untuk gedung auditorium menggunakan atap panel zincalume dengan struktur baja honeycomb, pipa galvanise, hollow galvanise dan seng plat zincalume.

Material dinding yang digunakan pada desain gedung konvensi yaitu untuk gedung pameran menggunakan material kaca dan struktur baja serta profil aluminium composit panel sedangkan untuk gedung auditorium menggunakan material dominan bata dan kaca. 


\section{nucture a nature}

National Academic Journal of Architecture

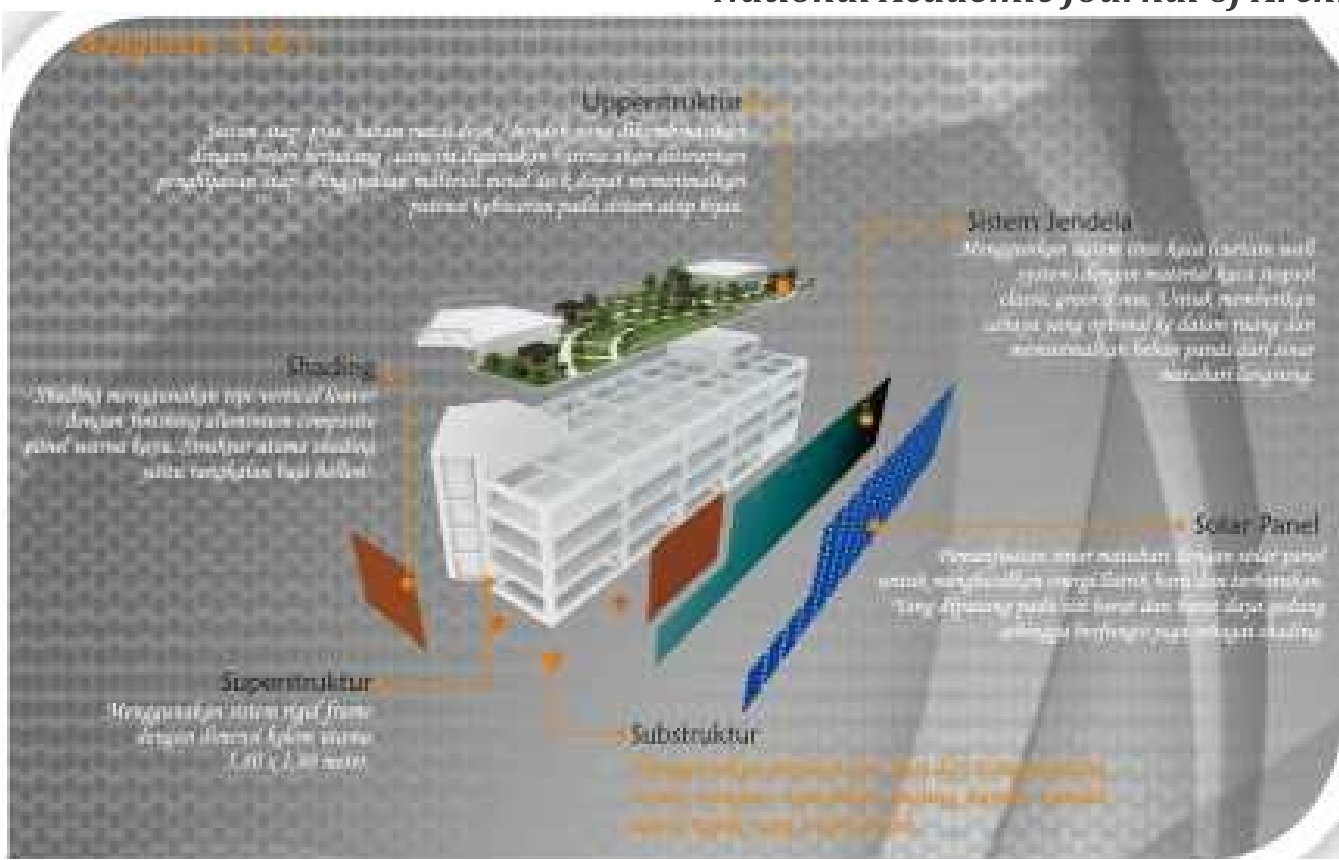

Gambar : Material dan Struktur Gedung Pameran

(Sumber : Olah desain, 2016)

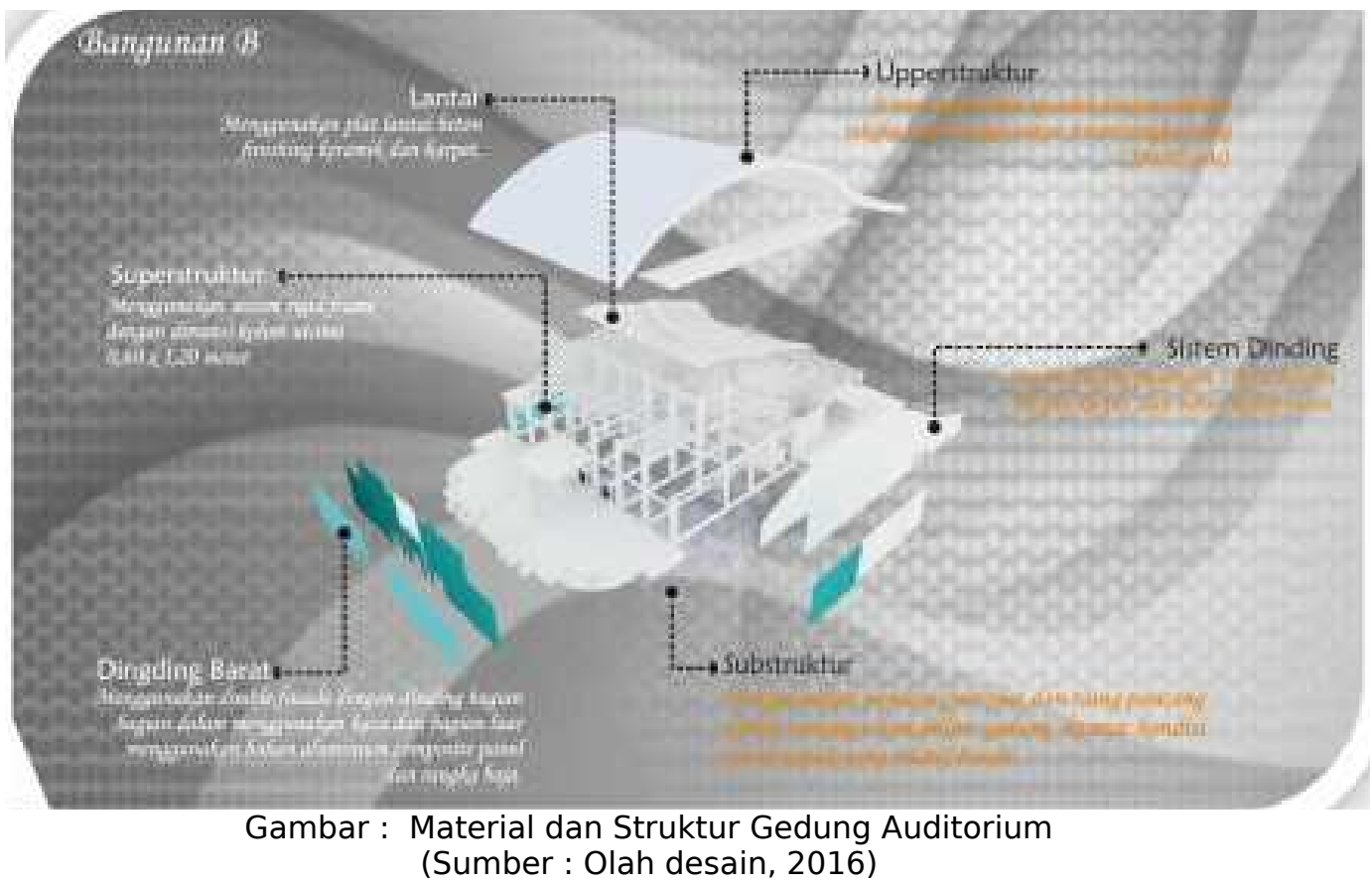
(Sumber : Olah desain, 2016)

D. Pendekatan Konsep Arsitektur Berkelanjutan

$\frac{\frac{\pi}{3}}{1}$

Tema desain gedung konvensi yang diterapkan pada desain gedung konvensi ini yaitu arsitektur berkelanjutan. Untuk merespon pemanasan global. 


\section{nucture naturel}

National Academic Journal of Architecture

Penerapan arsitektur berkelanjutan pada desian gedung konvesi yaitu pada lantai groundfloor dapat diakses oleh pengunjung umum, pada dinding selatan dan barat dipasang solar panel, pada atap digunakan greenroof, dan memanfaatkan air hujan dari atap.

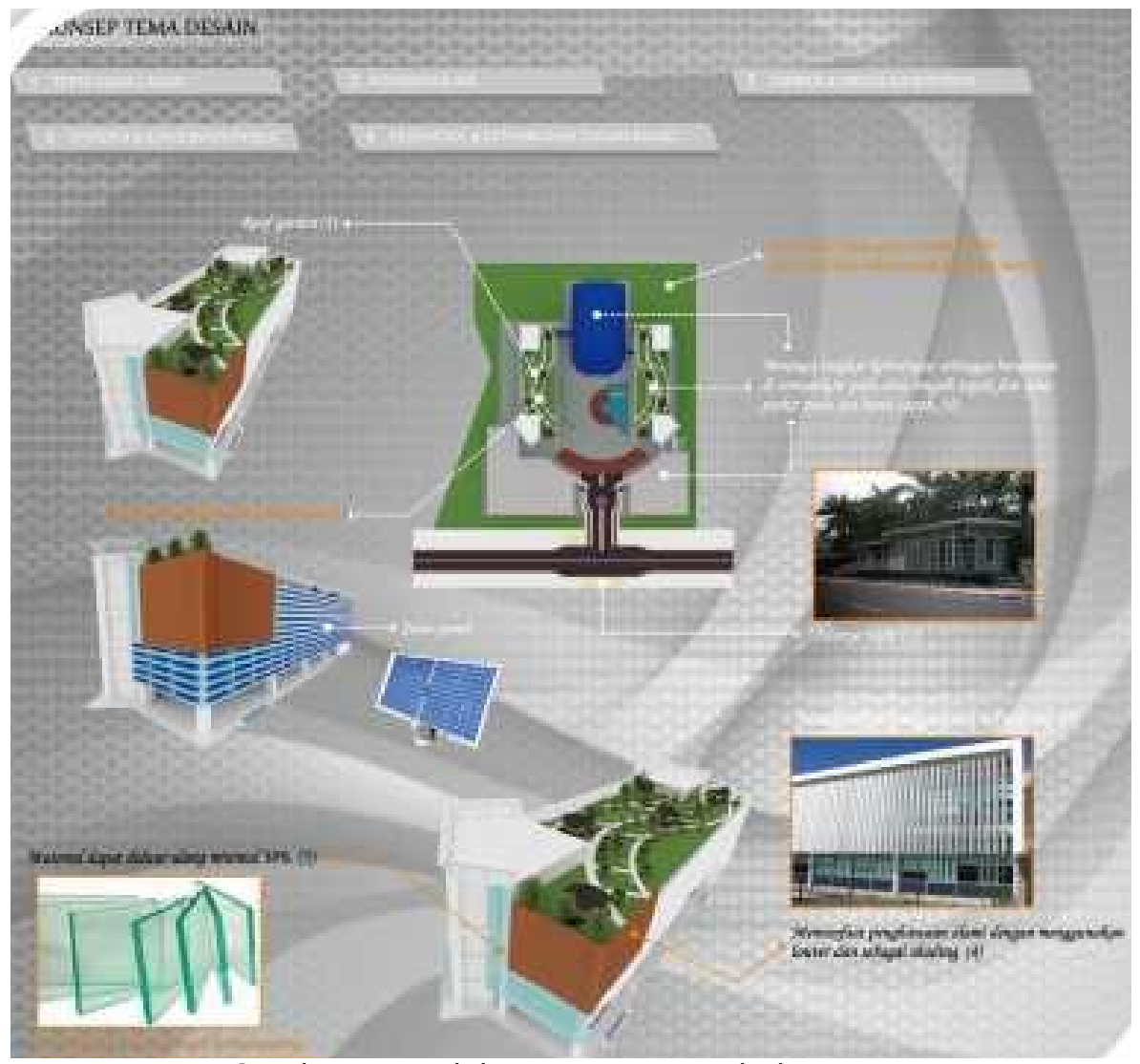

Gambar : Pendekatan Konsep Arsitektur

(Sumber : Olah desain, 2016)

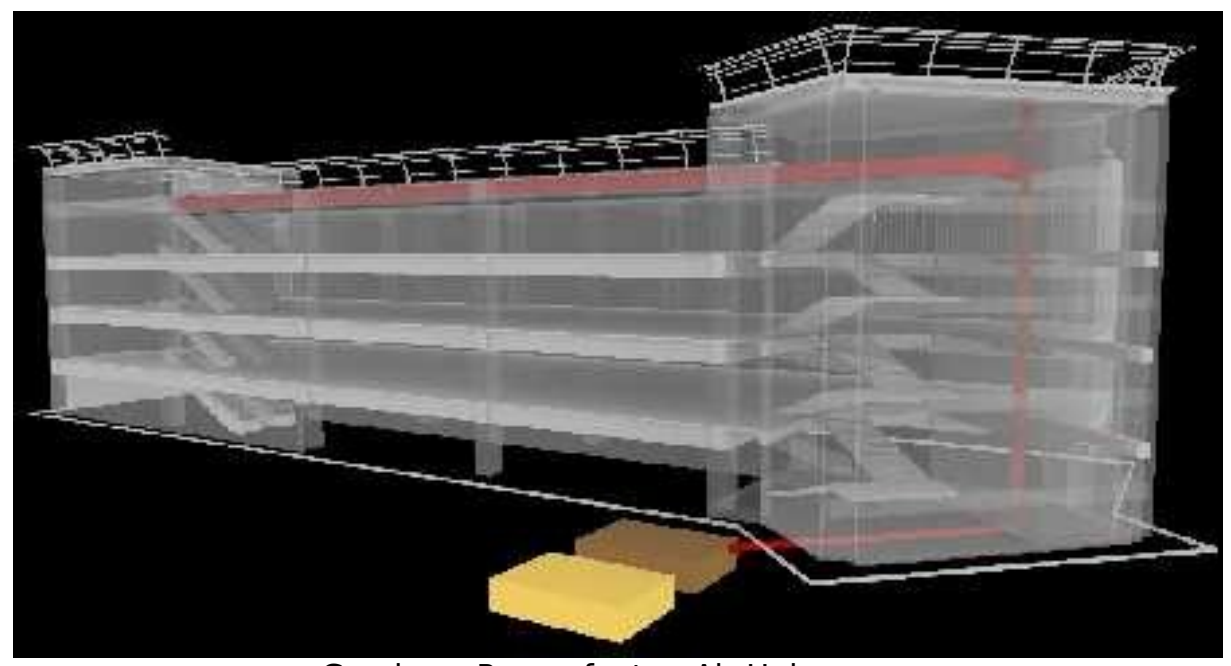

$N_{\frac{1}{\pi}}^{\frac{\pi}{\pi}}$

Gambar : Pemanfaatan Air Hujan 


\section{nucture naturel}

National Academic Journal of Architecture (Sumber : Hasil Desain, 2016)
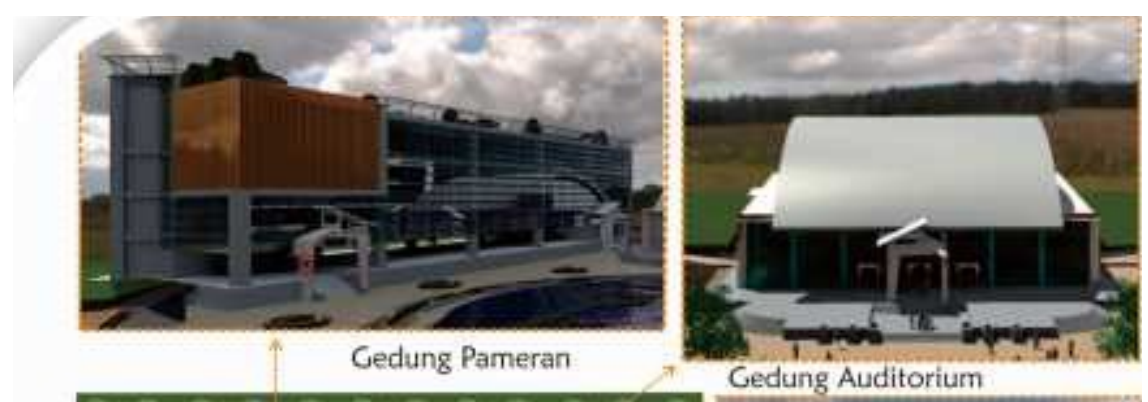

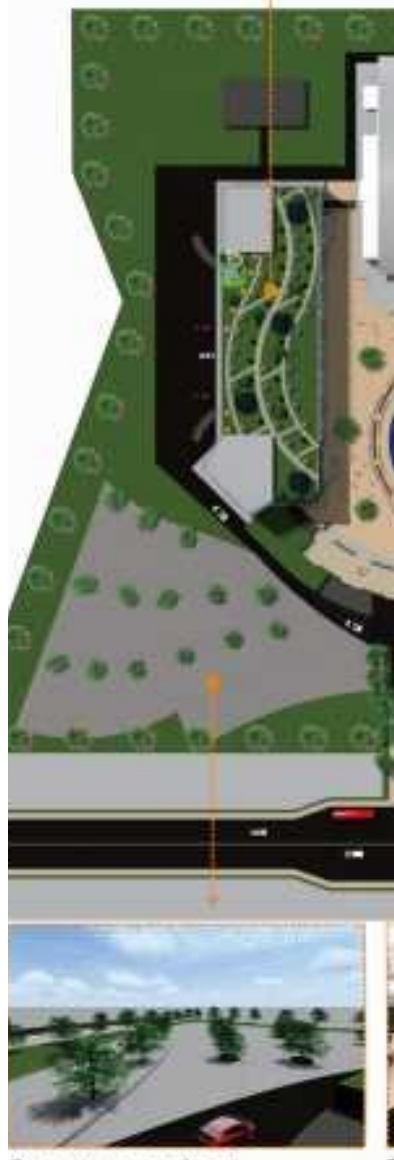

Pameran outdoor
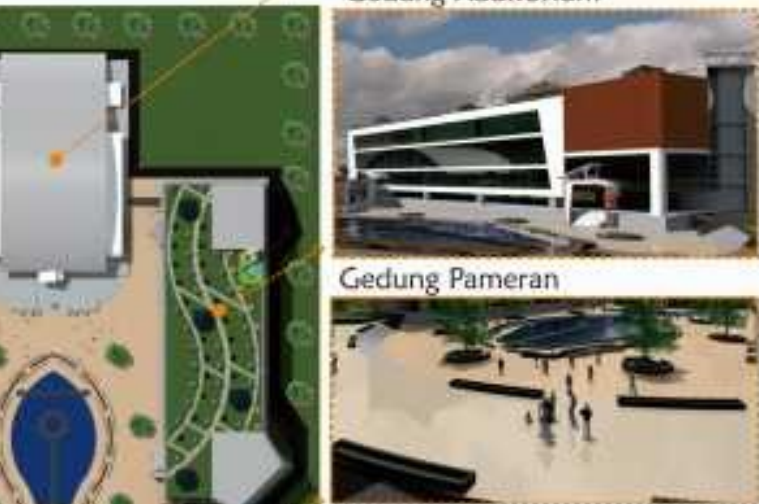

Plaza

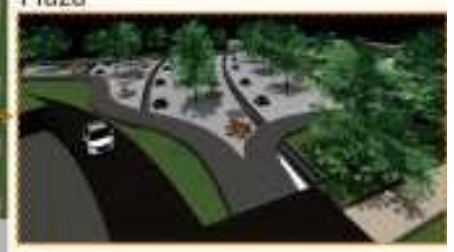

Taman

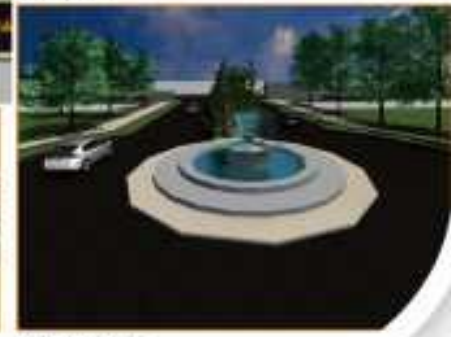

Enterance

Gambar : Tapak

(Sumber : Olah desain, 2016)

\section{$\infty$}

Tapak didesain dengan sistem sirkulasi yang nyaman baik bagi kendaraan maupun ह్ర manusia. Posisi pintu masuk kendaraan berada pada area yang aman untuk melakukan $\frac{\pi}{T}$ belokan masuk ke dalam tapak, untuk kendaraan angkutan kota disediakan halte yang aman dan nyaman untuk menurunkan penumpang dengan selamat. Untuk kendaraan pribadi dapat mengakses area parkir di lantai basement bangunan dengan mudah. Penumpang yang turun dari kendaraan umum dapat berjalan di area plaza yang dilengkapi fasilitas taman dengan bangku-bangku yang didesain unik untuk pengunjung yang ingin menikmati kenyamanan taman gedung konvensi. Massa bangunan berada 


\section{nucture

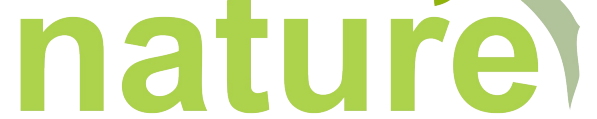

National Academic Journal of Architecture

ditengah tapak dan saling terhubung dan setiap bangunan terhubung langsung dengan area parkir dan plaza.

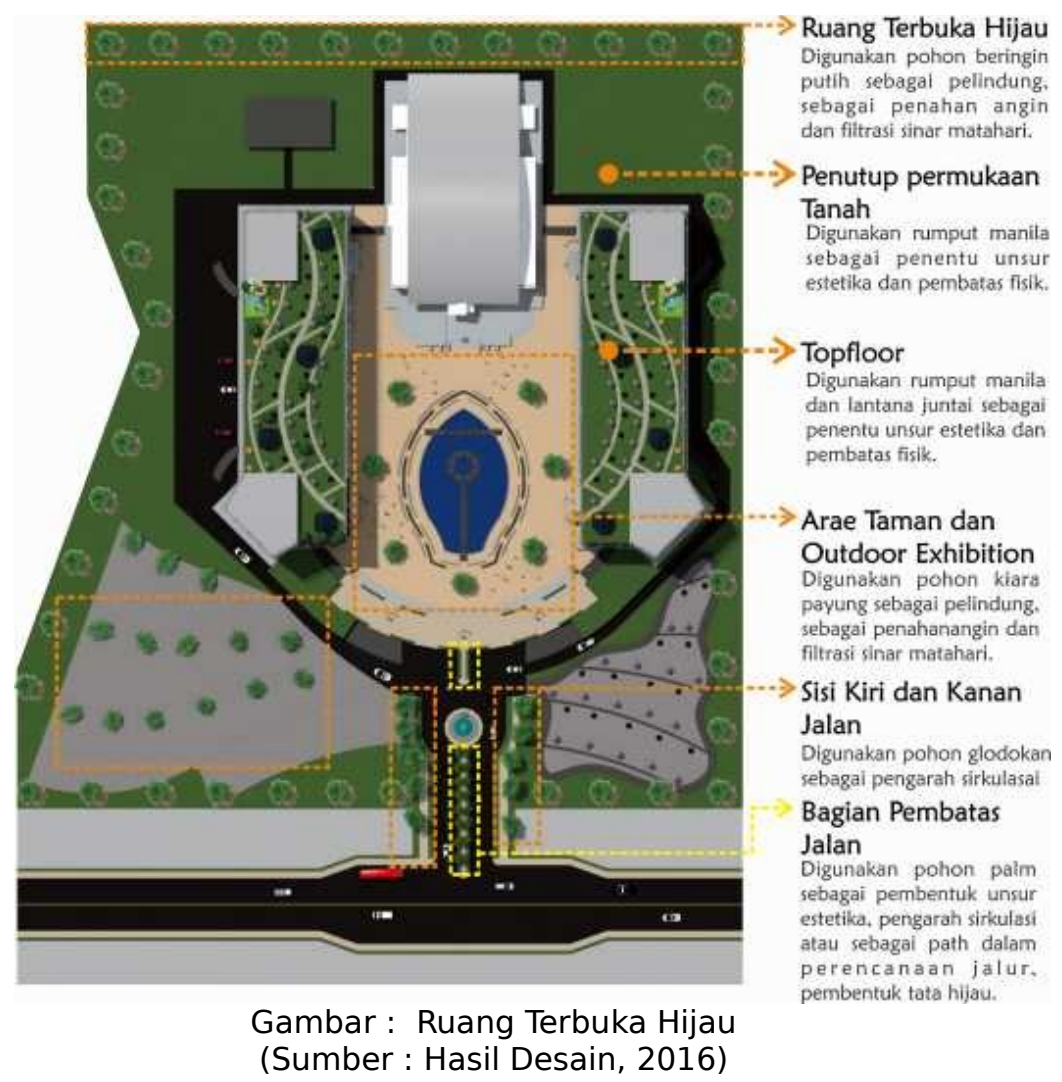

Area hijau didesain mengelilingi tapak untuk memberikan kenyamanan lingkungan tapak, pohon-pohon rindang diletakkan menyebar diseluruh area taman.

\section{E. Konsep Bentuk Bangunan}

Fasad bangunan terkesan modern tetapi tidak terlepas dari kriteria prasyarat yang ditelah ditetapkan oleh Green Building Council Indonesia (GBCI). Elemen-elemen pada fasade bangunan didesain sederhana serta mengutamakan fungsi dibanding bentuknya. 


\section{nucture naturel}

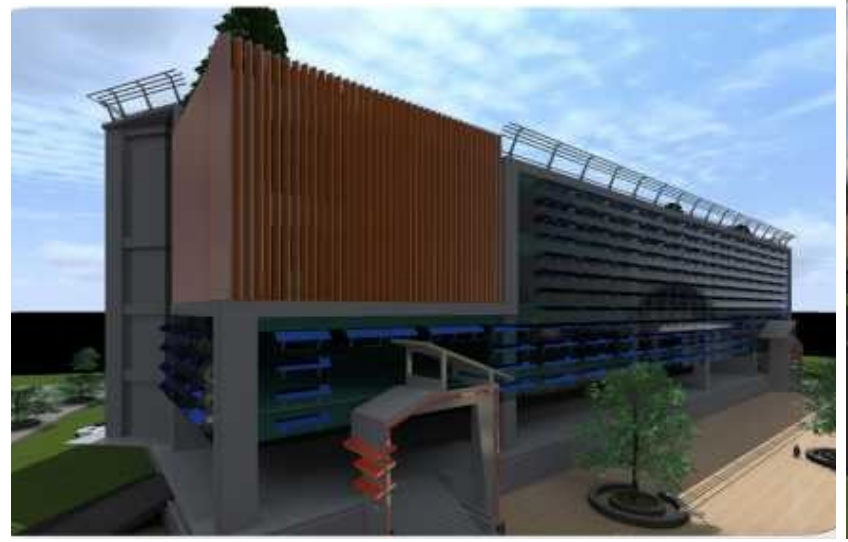

National Academic Journal of Architecture

Gambar :Gedung Pameran \& Rapat

(Sumber: Hasil Desain, 2016)

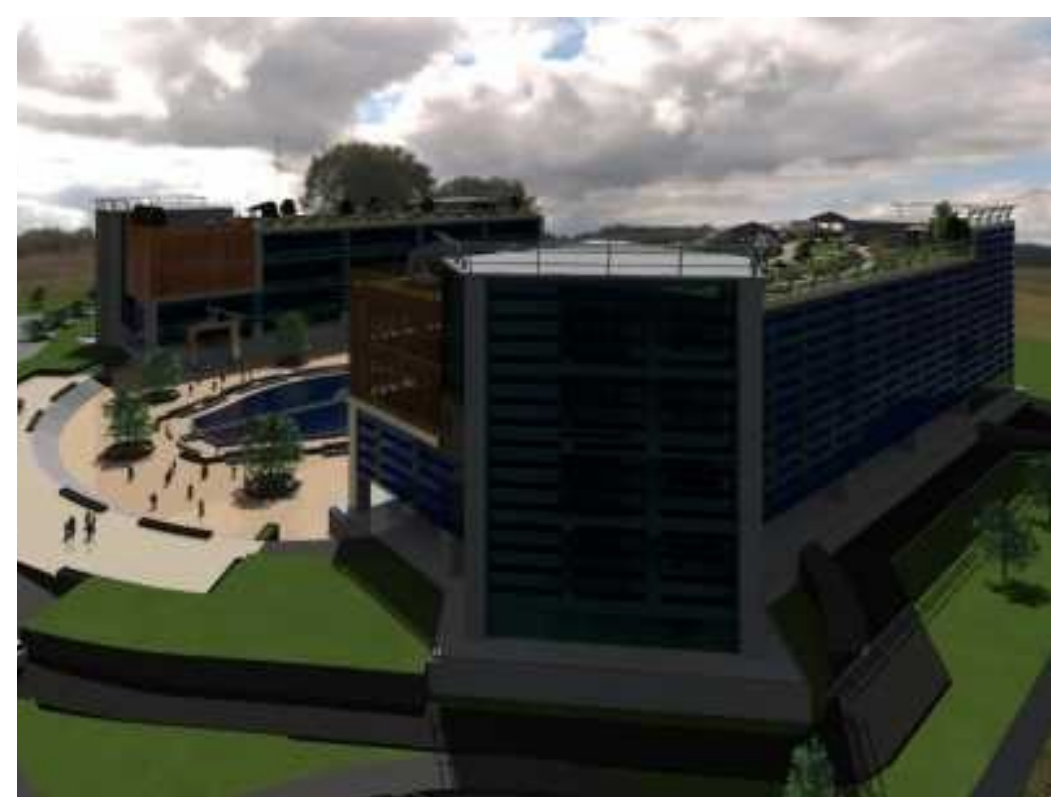

Gambar VI.4 Perspektif Gedung Pameran \& Rapat

(Sumber : Hasil Desain, 2016)

\section{KESIMPULAN}

- Kebutuhan akan Gedung Konvensi di Mamminasata Kabupaten Gowa sangat $\rightarrow$ penting bagi masyarakat. Ada empat fokus pembahasan dalam penulisan ini yaitu konsep tapak, bentuk bangunan, struktur/material, dan konsep berkelanjutan. ¿ Penerapan arsitektur berkelanjutan pada desian gedung konvesi yaitu pada lantai $\frac{\pi}{\pi}$ groundfloor dapat diakses oleh pengunjung umum, pada dinding selatan dan barat Iipasang solar panel, pada atap digunakan greenroof, dan memanfaatkan air hujan dari atap. 


\section{nucture naturel}

National Academic Journal of Architecture

\section{DAFTAR PUSTAKA}

Badan Standardisasi Nasional. 2000. Sistem Plambing. Bandung.

Ching, Francis D.K..2008. Arsitektur Bentuk, Ruang dan Tatanan. Edisi Ke 3.

Diterjemahkan oleh : Hanggan Situmorang. Jakarta : Erlangga. Ching, Francis D.K.2003. Ilustrasi Konstruksi Bangunan. Erlangga, Jakarta. Keputusan Menteri Kesehatan Republik Indonesia Nomor 1405 /Menkes /Sk /Xi/2002 Tentang Persyaratan Kesehatan Lingkungan Kerja Perkantoran dan Industri.

Keputusan Menteri Negara Lingkungan Hidup No. 48 Tahun 1996 Tentang : Baku Tingkat Kebisingan

Muatan Rencana Tata Ruang Wilayah. 2012. Kabupaten Gowa Neufert, Ernest. 1997. Data Arsitekjilid 1. Jakarta :

Erlangga. Neufert, Ernest. 2002. Data ArsitekJilid II. Jakarta : Erlangga. Neufert, Ernest. 1997. Data Arsitekjilid III. Jakarta : Erlangga. Nyoman, Andiani Dini. 2001. MICE. Bali : Undikasha

Pemerintah Kabupaten Gowa. 2012. Badan Koordinasi Penanaman Modal.

Pendit, Nyoman S. 1999. Wisata Konvensi. Jakarta : PT. Gramedia Pustaka Utama.

Rahman, M. Fatur. 2005. Kondominium Di Makassar. Jurusan Teknik Arsitektur, Fakultas Teknik, Universitas Hasanuddin.

Rizal, Muh. Fahrul. 2006. Convention Center. Jurusan Teknik Arsitektur, Fakultas Teknik, Universitas Hasanuddin.

Shihab, M. Quraish. 2004. Tafsir al mishbah: Pesan, Kesan dan Keserasian Al- Qur'an. Jakarta : Lentera Hati.

Undang Undang No 28 Tahun 2002. Tentang Bangunan Gedung.

Nawir, Muhammad Yahya. 2012. Pusat Pelatihan Autodesk dengan Pendekatan Hemat Energi Di Makassar. Jurusan Teknik Arsitektur, Fakultas Sains dan Teknologi, Universitas Islam Negeri Alauddin Makassar.

Zen, Muh.Rizal. 2006. Acuan perancangan Gedung Konvensi. Jurusan Teknik Arsitektur, Fakultas Teknik, Universitas Hasanuddin.

Website

http://kbbi.web.id/gedung, diakses 11 September 2015 http://iccaworld.com, diakses 11 September 2015 http://komitmenku.wordpress.com, diakses14 Mei 2015 http://www.bersosial.com, diakses 19 September 2015 http://www.budpar.go.id, diakses, 14 Mei 2015 http://www.p2par.itb.ac.id, 14 Mei 2015 http://www.tourismmakassar.com, 19 Juni 2015

http://www.visitsandiego.com, diakses 01 Agustus 2015 http://www.woc2014.com, diakses 01 Agustus 2015 http://www.aapexperience.org/, diakses 27 Mei 2015

http://www.klccconventioncentre.com, diakses 01 Agustus 2015 http://www.rvapc.com/works/, diakses 27 Mei 2015 http://www.klccconventioncentre.com/, diakses 27 Mei 2015 http://www.mybooking.co.id/, diakses 27 Mei 2015 


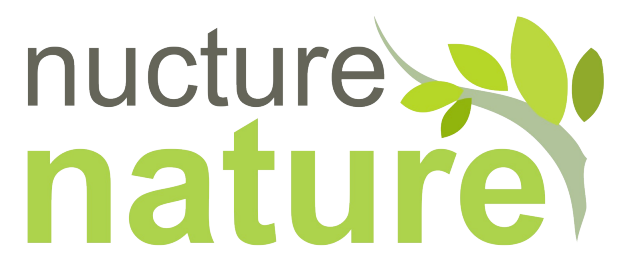

National Academic Journal of Architecture

N

న్

हึ

$\frac{\sqrt{3}}{1}$ 